\title{
Article
}

\section{Analysis of Crisis Management for Sustainable Development of Fitness Center during the COVID-19 Pandemic}

\author{
Tae-Seung Park ${ }^{1}(\mathbb{D})$ and Jae-Yoon Kwon ${ }^{2, *(1)}$ \\ 1 Department of Physical Education, Sejong University, 209, Neungdong-ro, Gwangjin-gu, Seoul 05006, Korea; \\ pts81@naver.com \\ 2 Department of Fitness MBA, Sangmyung University, Seoul 03016, Korea \\ * Correspondence: kwon-gun@hotmail.com; Tel.: +82-10-7445-1184
}

Citation: Park, T.-S.; Kwon, J.-Y. Analysis of Crisis Management for Sustainable Development of Fitness Center during the COVID-19 Pandemic. Sustainability 2022, 14, 2451. https://doi.org/10.3390/ su14042451

Academic Editors: Weisheng Chiu, Yu Huang and Sang-Back Nam

Received: 5 January 2022

Accepted: 16 February 2022

Published: 21 February 2022

Publisher's Note: MDPI stays neutral with regard to jurisdictional claims in published maps and institutional affiliations.

Copyright: (C) 2022 by the authors. Licensee MDPI, Basel, Switzerland. This article is an open access article distributed under the terms and conditions of the Creative Commons Attribution (CC BY) license (https:// creativecommons.org/licenses/by/ $4.0 /)$.

\begin{abstract}
The purpose of this research was to verify the importance and performance of sustainable crisis management in Korean fitness centers using Importance-Performance Analysis (IPA). For this study, 304 fitness center executives and managers in Seoul and Gyeonggi region were selected from 21 March to 17 May 2020. Frequency analysis was performed using SPSS 24.0, and exploratory factor analysis was conducted to verify the validity and reliability. Priority analysis and IPA analysis were performed to compare the mean values, and the following results were obtained. In the first quadrant, there were six attributes besides keeping social distancing between employees and customers. In the second quadrant, there were four attributes in addition to regular disinfection of the gymnasium. In the third quadrant, there were six attributes besides maintain clean furniture. Third, there were six attributes other than maintaining clean furniture in the third quadrant. Lastly, in the fourth quadrant, there were three attributes in addition to the restriction of face-to-face meetings. The conclusion was as follows. First, equip supplies for the prevention of COVID-19, keep social distance, and check government support policies. Second, analyze economic support policies, and research their application methods. Third, prepare various non-face-to-face communication methods and Untact (noncontact) marketing strategies. Fourth, make a checklist for factors with relatively little importance.
\end{abstract}

Keywords: COVID-19; sustainable development crisis management; Korean fitness center; ImportancePerformance Analysis

\section{Introduction}

At present, the entire world is facing major changes in the social, educational, and economic sectors due to Corona Virus disease 2019 (COVID-19). Schools have been conducting classes online, companies have been allowing employees to work from home, and people have been unable to access indoor gyms due to lockdowns and stringent social distancing policies to minimize the spread of the virus. Moreover, due to the enforcement of strict quarantine policies in many countries [1], religious, entertainment, and indoor and outdoor public sports facilities have been forcibly closed. Sporting and sports activities have been restricted in most indoor and outdoor spaces, excluding residential spaces [2].

The 2020 Tokyo Olympics were postponed due to the outbreak of this infectious disease [3]; this was the first time in 124 years. In addition, worldwide live sporting events were played with empty stadiums, i.e., without any spectators [4]. Fans have been confused by the relevant regulations and resumption conditions, which are different for each league; this is not only due to the operational aspects of professional sports clubs but also due to the regulations and conditions, which differ based on leagues [5,6]. The outbreak of the COVID-19 pandemic worldwide led to a national lockdown starting on 12 March 2020. The lockdown included, among others, closing of all fitness centers, organized sports and sports events, and the whole community was advised to keep social distance. Fitness 
centers were closed all over East Asia [7,8], and with the exception of some countries such as Norway [9] and Spain [10] in Europe, they are experiencing great difficulties in sustainable management. It is not possible to generalize that fitness centers in all countries are experiencing a crisis, but it is true that fitness centers in most countries are closed and have difficulties. Moreover, as per the data on the COVID-19 emergency drawn from a survey on Korea's sports industry conducted by the Korean government, the closure rate for renting facilities and construction (37.0\%) of stadiums and gyms and sports service business (52.8\%), including sports marketing and sports racing, was higher than for the sporting goods industry $(7.8 \%)$. The fitness industry has been facing a significant crisis since March 2020, where sales have been limited, and the number of employees who were laid off exceeded for the entire sports industry ( $35.9 \%$ ) (Taekwondo $=73.7 \%$, yoga, and Pilates $=65.2 \%$, and fitness centers $=80.3 \%$ ) [2]. The spread of COVID-19 is causing enormous damage to various industries related to sports, and among them, the global fitness industry is being hit the hardest. Therefore, in the current situation, there is a need for a management plan that can provide the fitness industry sustainable development. This study may have value in contributing to fitness crisis management at this point.

The fitness industry in Korea is experiencing unprecedented difficulties due to the imposition of various regulations to control the spread of COVID-19. It is essential to improve the risk management ability of managers and executives in this field to handle the COVID-19 pandemic effectively [11]. Research should be conducted to establish a deeper understanding of perceptions on overcoming the crisis of fitness centers where the scale of damage is relatively high. It is difficult for fitness centers in most countries to sustainably develop business due to COVID-19. This resesarch can be differentiated in that it was conducted from a manager's point of view, unlike previous customer-centered studies.

Importance-performance analysis (IPA) can thus be used to compare and analyze the importance and achievement of the crisis management of sustainable development measures adopted by fitness center executives and managers to present solutions and strategies on the abovementioned concerns. The analytical process of IPA is simple, the outcomes are easy to interpret, and the results focus on the presentation of the problem. These aspects enable multidimensional comparative analysis of the crisis management plan of the fitness center $[12,13]$.

IPA is employed while studying varied subjects, such as marketing, banking, education, sports, and health, to improve these areas by evaluating consumer products and services [14]. This factor can therefore provide an important basis for deriving an effective strategy to improve crisis management strategies of sustainable development fitness centers during COVID-19.

However, studies related to sports and fitness during the pandemic have largely focused on means of exercising at home in these novel circumstances [15], on the relationship between exercise and the immune [16], or novel regulations for fitness centers with research and development [17].

These works indicate that active research has been conducted on how fitness approaches should respond to the COVID-19 pandemic, such as policy suggestions and methods to continue exercising at home; however, little work is being done to respond to the continuous crisis occurring in fitness centers. As COVID-19 continues to spread, IPA study of crisis management in fitness centers, focusing on the managers who operate fitness centers, should be differentiated from other works intended to overcome the fitness industry crisis during the pandemic. Therefore, this study has a novelty that differentiates it from previous studies related to business from the customer's point of view.

This study investigates the necessary factors in current crisis management. This factor can therefore provide an important basis for deriving an effective strategy to improve crisis management strategies of sustainable development fitness centers during COVID-19. According to the opinion of fitness center executives and managers, it is possible to evaluate whether fitness center is being operated properly is assessed through IPA analysis. In addition, we examined what the ideal points were for further pursuit regarding fitness 
centers, and we analyzed the following four areas: maintenance of the current state, intensive improvement, inferior rankings, and the avoidance of excessive effort through matrix analysis. Hence, we seek to provide strategies for practical application to fitness centers and establish a crisis management system for practical use.

\section{Literature Review}

\subsection{Crisis Management in Korean Fitness Centers}

Crisis management refers to the way that an organization deals with a disruptive and unexpected event that threatens to harm the organization [18]. It is important to respond appropriately during all the stages of crisis management, namely the pre-crisis, crisis response, and post-crisis stages [19]. Crisis management is a crucial element of a company's conduct of its operations because it can either be perceived as a risk or an opportunity. In particular, crisis management is important for sustainable development in a crisis situation such as the COVID-19 pandemic [20]. During the pandemic, companies need to implement secure procedures and operate under an effective crisis management system to allow them to detect and prepare for crises in advance and respond effectively when crises occur, alongside proceeding to the normalization and crisis learning stages [21]. There were about 99,000 fitness operators in Korea in 2020, suggesting a 54\% increase over the past decade. It can be observed that expansion of the fitness market has led to growth throughout the fitness industry, although it has led to an overheating of market competition in reality. The three-year closure rate following opening is $24.3 \%$ [2], and this percentage is expected to have worsened since the onset of the pandemic.

A crisis management strategy of sustainable development is thus essential to ensure competitiveness in the fitness market. We analyze the crisis management plan of Korean fitness centers in operation during the COVID pandemic, dividing the approaches into management, finance, prevention, distance, disinfection, and cleanliness.

\subsection{Importance-Performance Analysis}

The concept of IPA was introduced in 1977 by Martilla and James [22] to analyze customer satisfaction with an organization's products or services. It has the advantage of being assumed with a simple statistical method that compares the average values. Although this approach was originally developed for marketing, it has been extended to various fields, including education [12,13], services [23,24], fitness [25,26], and public administration $[23,24]$. As shown in Figure 1 , the $y$-axis indicates the perceived importance of each attribute, and the $x$-axis shows the perceived product or system performance of each attribute. The explanation of the original IPA is presented in a scatter plot that divides the chart into four quadrants [27]. Not all quadrants measure values uniformly, and in some studies, "possible overkill" quadrants do not contribute to the overall outcome [28], using the following identifying phrases: "keep up the good work" (QI), "concentrate here" (QII), "possible overkill" (QIII), and "low priority" (QIV) [10]. This study is expected to provide valuable information for evaluating crisis management and its use in fitness centers under COVID-19; it is also believed that the matrix and four quadrants can provide useful information for prioritizing items for improvement. Each quadrant in IPA is divided by the importance of attributes from high to low (in the vertical axis) and the performance of attributes from high to low (in the horizontal axis). As a result, the disparity between importance and performance can be established. 


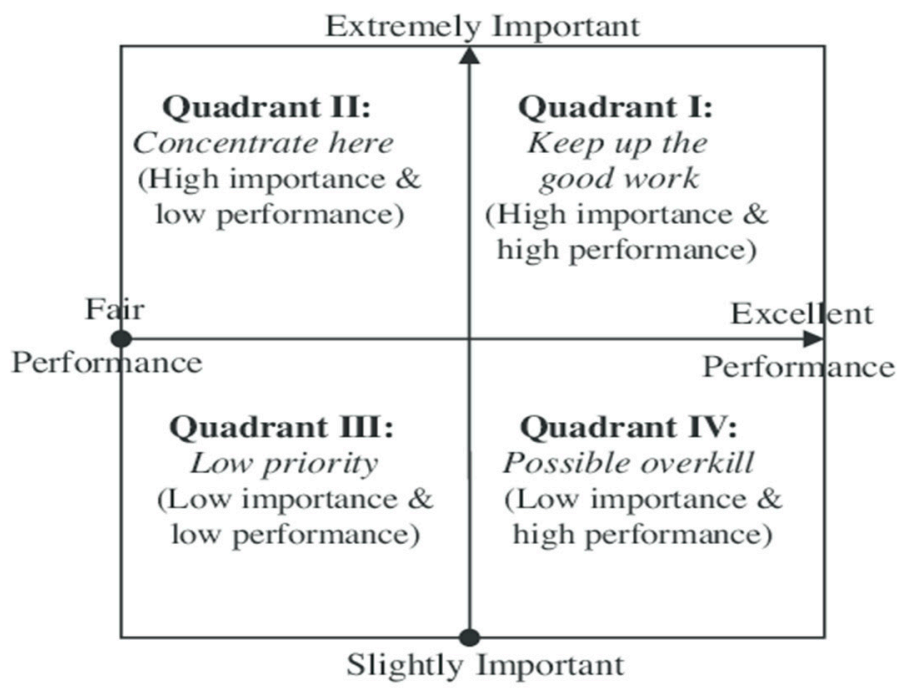

Figure 1. Importance-Performance Analysis (IPA) matrix.

\section{Materials and Methods}

\subsection{Participants and Procedure}

This study was conducted with the approval of the Research Ethics Committee (IRBSMU-C-2020-4-019). The subjects were executives and managers currently operating fitness centers in Seoul and Gyeonggi. Samples were extracted from 21 March to 17 May 2020, using the judgment method, a nonprobability sampling technique wherein the members are selected using the researcher's knowledge and judgment. A total of 320 questionnaires were distributed online, as face-to-face contact and group activities were not allowed. A selfadministration method was used to fill out the questionnaires, and of these, 16 were eliminated based on a lack of information and low validity. All subjects were able to respond to the survey, composed on and distributed via Google, on a computer, or a mobile phone, and the data were collected through a linked URL or messenger. The questionnaire was self-administered to address individual thoughts and feelings. Among the questionnaires collected, 304 copies were selected as valid samples, excluding 16 incomplete questionnaires.

Of the respondents, $78.3 \%(n=238)$ were males and $21.7 \%(n=66)$ were females. The age range was $3.6 \%$ in their $20 \mathrm{~s}(n=11), 27.3 \%$ in their $30 \mathrm{~s}(n=83), 35.9 \%$ in their $40 \mathrm{~s}$ $(n=109)$, and $33.2 \%$ in their $50 \mathrm{~s}$ and older $(n=101)$. The types of business were sole fitness proprietorship, $26.3 \%(n=80)$ and fitness franchise, $73.7 \%(n=224)$. Operations had been underway for less than 1 year in $10.8 \%(n=33), 1-5$ years in $23.4 \%(n=71), 5-10$ years in $40.5 \%(n=123)$, and more than 10 years in $25.3 \%(n=29)$. After the onset of the COVID-19 pandemic, $81.9 \%(n=249)$ entered into significant crisis, $8.6 \%(n=26)$ in moderate crisis, and $9.5 \%(n=29)$ in minimal crisis. After the recommendation that business be suspended, the level of reduction in sales for $12.5 \%$ was at the $30 \%$ level $(n=38)$; for $23.4 \%$, it was at the $60 \%$ level $(n=71)$; and for $64.1 \%$, it was at the $90 \%$ level $(n=195)$. The most serious current problems are the difficulty of attracting the return of existing members for $20.4 \%(n=62)$, paying taxes and rent for $21.5 \%(n=65)$, frequent closures for $3.9 \%(n=12)$, management and economic downturn for $10.9 \%(n=33)$, lack of government support for $11.8 \%(n=36)$, financial problems for $29.9 \%(n=91)$, and others for $1.6 \%(n=5)$.

\subsection{Measurement}

A questionnaire was employed to gather data, and all questions and variables were constructed based on previous studies and theories considered suitable for the present study. The questionnaire items were created from the Delphi survey items, reflecting top-down opinions obtained through repeated feedback from five panelists, consisting of field experts and professors of sports industry management for items that could not be derived from previous studies or be newly derived. Through feedback from the 1st, 2 nd, 
and 3rd Delphi surveys, the reliability and validity of the selected items were secured, and a survey was conducted by securing the content validity of the completed questionnaire.

The questionnaire constructed through exploratory factor analysis consists of three parts: 7 questions on personal characteristics, 24 questions on the importance of crisis management in fitness centers, and 24 questions on execution for crisis management in fitness centers (Total $=55$ questions). These questions were revised from a study on the development of risk management consulting [29], survival strategies of the sports industry following the emergence of the COVID-19 pandemic [30], and measures for improvement that relate to crisis factors not related to financial management [31]. The importance and performance of variables for crisis management in Korean fitness center variables are composed from values related to business, financial, preventive, distance, disinfection, and cleanliness. As a result of the reliability of internal consistency through Cronbach's $\alpha$ test, the values ranged from a minimum of 0.798 to a maximum of 0.915 , securing reliability for importance and performance. The questionnaires were measured on a 5-point Likert scale, ranging from "strongly disagree" (1) to "strongly agree" (5). Table 1 shows the IPA factor analysis results of crisis management.

Table 1. Questionnaire items and factor loadings from EFA: Importance and performance factors of crisis management.

\begin{tabular}{|c|c|c|c|c|c|c|c|}
\hline Factor & Items & BM & FM & PM & DM1 & DM2 & $\mathrm{CM}$ \\
\hline \multirow{4}{*}{$\begin{array}{c}\text { Business } \\
\text { management }\end{array}$} & Notice of operation date & 0.932 & & & & & \\
\hline & Customer service phone & 0.918 & & & & & \\
\hline & Quarantine notice & 0.876 & & & & & \\
\hline & Information about refund and postponement & 0.962 & & & & & \\
\hline \multirow{4}{*}{$\begin{array}{c}\text { Financial } \\
\text { management }\end{array}$} & Applying for government stimulus check & & 0.904 & & & & \\
\hline & Find ways to reduce the rent & & 0.892 & & & & \\
\hline & Apply for deferred payment & & 0.871 & & & & \\
\hline & Apply for sports industry subsidy & & 0.845 & & & & \\
\hline \multirow{4}{*}{$\begin{array}{l}\text { Preventive } \\
\text { management }\end{array}$} & Prepare hand sanitizers & & & 0.881 & & & \\
\hline & Equipped with a thermometer & & & 0.815 & & & \\
\hline & Prepare extra masks & & & 0.789 & & & \\
\hline & Equipped with a noncontact thermometer & & & 0.778 & & & \\
\hline \multirow{4}{*}{$\begin{array}{c}\text { Distance } \\
\text { management }\end{array}$} & Social distancing between employees and customers & & & & 0.846 & & \\
\hline & Install transparent partitions & & & & 0.836 & & \\
\hline & Limited face to face time & & & & 0.816 & & \\
\hline & Notification of quarantine & & & & 0.752 & & \\
\hline \multirow{4}{*}{$\begin{array}{l}\text { Disinfection } \\
\text { management }\end{array}$} & Planning and establishment of quarantine & & & & & 0.813 & \\
\hline & Disinfection of equipment & & & & & 0.782 & \\
\hline & Disinfection of the gym & & & & & 0.771 & \\
\hline & Request government disinfection control & & & & & 0.755 & \\
\hline \multirow{8}{*}{$\begin{array}{l}\text { Cleanliness } \\
\text { management }\end{array}$} & Ensure employees practice good hand hygiene & & & & & & 0.774 \\
\hline & Keep entrances and hallways clean & & & & & & 0.765 \\
\hline & Improve toilet ventilation & & & & & & 0.73 \\
\hline & Maintain furniture clean & & & & & & 0.711 \\
\hline & Eigenvalues & 3.561 & 3.317 & 3.218 & 2.735 & 2.699 & 2.451 \\
\hline & $\%$ of Variance & 15.361 & 14.81 & 13.218 & 11.224 & 11.105 & 9.659 \\
\hline & Cumulative \% & 15.361 & 30.171 & 43.389 & 54.613 & 65.718 & 75.377 \\
\hline & Cronbach's $\alpha$ & 0.915 & 0.902 & 0.896 & 0.847 & 0.828 & 0.798 \\
\hline
\end{tabular}

Note: $\mathrm{BM}=$ business management; FM = financial management; $\mathrm{PM}$ = preventive management; DM1 = distance management; $\mathrm{DM} 2$ = disinfection management; $\mathrm{CM}=$ Cleanliness management.

\subsection{Data Analysis}

Ultimately, the 304 questionnaires used in the statistical analysis were conducted using SPSS version 24.0. The method of analysis included the following aspects. First, 
for the demographic characteristics and consensus of the study, a frequency analysis was conducted. Second, to verify the importance and performance priority of crisis management in the Korean fitness centers and to analyze the coordinates of each quadrant, the final verification was performed using the IPA matrix.

\section{Results}

\subsection{Priority Analysis of Importance and Performance of Fitness Center Crisis Management}

Table 2 presents the importance and achievement of fitness center crisis management. Among fitness center risk management factors, preventive management was the most important, at 4.08 , followed by finance at 4.06 , disinfection management at 3.91 , social distancing at 3.88, cleanliness at 3.66, and business management at 3.56. In particular, obtaining a noncontact thermometer, finding a way to lower monthly rent, regular disinfection of the gym, social distancing between employees and customers, educating employees on handwashing, and giving advance notification regarding closed days were considered the most important values. Next, among risk management factors, preventive management was considered to be the best implemented, at 4.12 , followed by cleanliness management at 3.90, distance management at 3.77, business management at 3.56, financial management at 3.51, and disinfection management at 3.44. Specifically, for this reason, spare masks were provided for preventive management, toilet ventilation was improved for cleanliness management, limitations to the length of time of face-to-face meetings with customers were imposed for distance management, customer inquiries were handled over the phone for business management, application for government stimulus checks was performed for financial management, and planning and establishment of quarantine were performed for disinfection management.

Table 2. Importance-Performance and priority analysis fitness center crisis management.

\begin{tabular}{|c|c|c|c|c|c|c|c|}
\hline \multirow{2}{*}{ Factor } & \multirow{2}{*}{ Questionnaires } & \multicolumn{3}{|c|}{ Importance } & \multicolumn{3}{|c|}{ Performance } \\
\hline & & \multirow{2}{*}{$\begin{array}{c}\text { Rank } \\
10\end{array}$} & \multicolumn{2}{|c|}{$M \pm S D$} & \multirow{2}{*}{$\begin{array}{c}\text { Rank } \\
12\end{array}$} & \multicolumn{2}{|c|}{$M \pm S D$} \\
\hline \multirow{4}{*}{$\begin{array}{c}\text { Business } \\
\text { management }\end{array}$} & Notice of business hours & & 4.04 & 0.765 & & 3.78 & 0.721 \\
\hline & Handling customer inquiries over the phone & 17 & 3.77 & 0.914 & 8 & 3.98 & 0.789 \\
\hline & Communication with customers regarding quarantine & 24 & 3.12 & 0.864 & 23 & 3.14 & 0.851 \\
\hline & Deliver information about refund and automatic deferral guidance & 21 & 3.32 & 0.828 & 21 & 3.35 & 0.901 \\
\hline \multirow{4}{*}{$\begin{array}{c}\text { Financial } \\
\text { management }\end{array}$} & Apply for government stimulus check & 8 & 4.07 & 0.794 & 10 & 3.87 & 0.863 \\
\hline & Find ways to reduce the rent & 7 & 4.09 & 0.719 & 24 & 3.07 & 0.911 \\
\hline & Apply for deferred payment & 9 & 4.05 & 0.806 & 19 & 3.45 & 0.915 \\
\hline & Apply for sports industry subsidy & 12 & 4.01 & 0.905 & 14 & 3.64 & 0.905 \\
\hline \multirow{4}{*}{$\begin{array}{c}\text { Preventive } \\
\text { management }\end{array}$} & Provide hand sanitizers & 4 & 4.15 & 0.889 & 7 & 3.99 & 0.947 \\
\hline & Equipped with a thermometer & 3 & 4.32 & 0.892 & 5 & 4.1 & 0.963 \\
\hline & Provide spare masks & 19 & 3.55 & 0.994 & 1 & 4.22 & 0.916 \\
\hline & Equipped with a noncontact thermometer & 2 & 4.33 & 0.882 & 3 & 4.16 & 0.905 \\
\hline \multirow{4}{*}{$\begin{array}{l}\text { Social distancing } \\
\text { management }\end{array}$} & Social distancing between employees and customers & 1 & 4.4 & 0.962 & 11 & 3.85 & 0.908 \\
\hline & Install transparent partitions & 15 & 3.89 & 0.989 & 16 & 3.56 & 0.954 \\
\hline & Limit the time and length of face-to-face meetings with customers & 14 & 3.94 & 1.029 & 4 & 4.13 & 0.856 \\
\hline & Guidance on quarantine regulations & 22 & 3.28 & 1.038 & 17 & 3.55 & 1.117 \\
\hline \multirow{4}{*}{$\begin{array}{l}\text { Disinfection } \\
\text { management }\end{array}$} & Plan and establishment of quarantine & 18 & 3.56 & 1.074 & 13 & 3.69 & 1.089 \\
\hline & Disinfect equipment & 6 & 4.1 & 0.982 & 22 & 3.15 & 0.989 \\
\hline & Regular disinfection of the gym & 5 & 4.13 & 0.883 & 20 & 3.36 & 0.878 \\
\hline & Apply for disinfection of regional quarantine & 16 & 3.85 & 0.876 & 15 & 3.57 & 0.994 \\
\hline \multirow{4}{*}{$\begin{array}{l}\text { Cleanliness } \\
\text { management }\end{array}$} & Ensure employees practice good hand hygiene & 11 & 4.02 & 0.887 & 9 & 3.92 & 0.918 \\
\hline & Keep entrances and hall ways clean & 23 & 3.25 & 0.888 & 5 & 4.01 & 0.925 \\
\hline & Improve toilet ventilation & 20 & 3.38 & 0.932 & 2 & 4.21 & 0.865 \\
\hline & Maintain furniture clean & 13 & 3.98 & 0.765 & 19 & 3.45 & 0.944 \\
\hline & Total & \multicolumn{3}{|c|}{4.01} & \multicolumn{3}{|c|}{3.72} \\
\hline
\end{tabular}

\subsection{IPA Matrix of Fitness Center Crisis Management}

An IPA analysis was employed to simultaneously analyze the relative importance and achievement of each attribute for crisis management of sustainable development in fitness 
centers. In general, IPA analysis performed using a matrix includes methods of calculating intersection points based on the standard deviation and a process of automatically converting a statistical program at random. In this study, the average value (mean) for importance and achievement was derived by setting the center point for each axis as the IP intersection point. The $x$-axis was divided into importance attributes, and the $y$-axis was divided into four quadrants, with the analytical results shown in Figure 2 and Table 3.

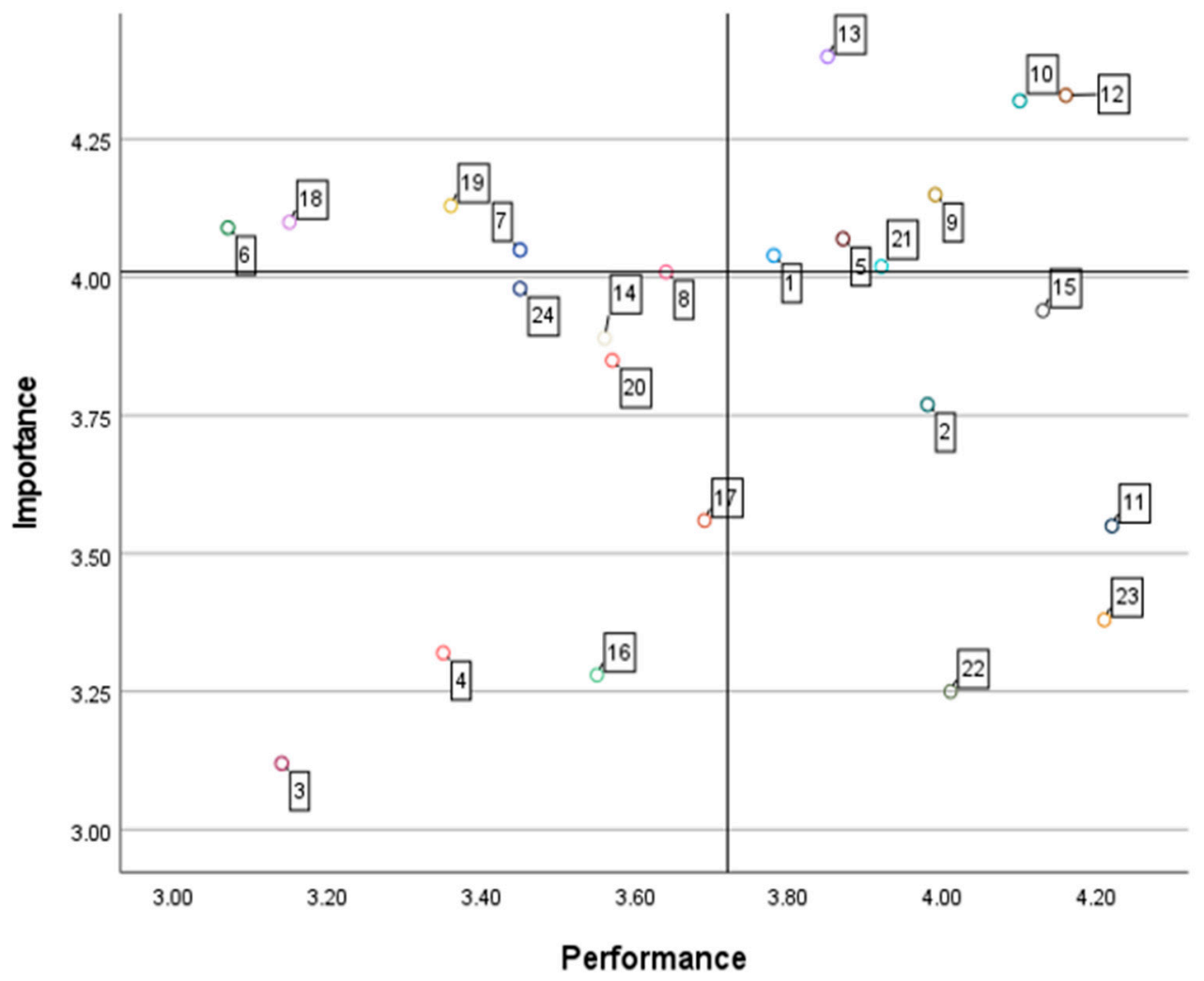

Figure 2. Importance-Performance Analysis (IPA) matrix of fitness center crisis management.

Table 3. IPA matrix results of Fitness Center Crisis Management.

\begin{tabular}{cc}
\hline Quadrant & Items \\
\hline Quadrant 1 & $\begin{array}{c}\text { Social distancing between employees and customers, Equipped with } \\
\text { a noncontact thermometer, Equipped with a thermometer, Provide } \\
\text { hand sanitizers, Apply for government stimulus check, Notice of } \\
\text { business hours, Ensure employees practice good hygiene }\end{array}$ \\
\hline Quadrant 2 & $\begin{array}{c}\text { Regular disinfection of the gym, disinfect the equipment, Find ways } \\
\text { to reduce the rent, Apply for deferred payment, Apply for sports } \\
\text { industry subsidy }\end{array}$ \\
Quadrant 3 & $\begin{array}{c}\text { Maintain furniture clean, Install transparent partitions, Apply for } \\
\text { disinfection of regional quarantine, Planning and establishment of } \\
\text { quarantine, Communication with customers about quarantine }\end{array}$ \\
\hline & $\begin{array}{c}\text { Limit the time of face-to-face meetings, Handling customer inquiries } \\
\text { over the phone, Provide spare mask, Improve toilet ventilation, } \\
\text { Keep entrances and hallways clean }\end{array}$ \\
\hline
\end{tabular}

Here, QI, indicating high importance and high performance for crisis management in fitness centers, includes social distancing between employees and customers, equipped with a thermometer, providing hand sanitizer, applying for government stimulus, providing notification of new operating hours, and ensuring that employees practice good hand hygiene. QII, indicating relatively low achievement but high importance, includes 
comprised regular disinfection of the gym, disinfection of equipment, finding ways to reduce rent, applying for deferred payment, and applying for a sports industry subsidy. QIII, indicating low importance and low achievement, includes maintaining clean furniture, installing transparent partitions, applying for the disinfection of regional quarantine, planning and establishing quarantine, guidance, and information on refunds and deferral, guidance on quarantine regulations, along with communication with customers about quarantine. QIV, indicating low importance and high achievement, is composed of limiting the time and length of face-to-face meetings with customers, handling customer inquiries over the phone, providing spare masks, improving toilet ventilation, and keeping the entrances and hallways clean.

This study performed a comprehensive analysis of the most important factors in executive and managerial thinking and the ways in which these appear in their course of business. The study results indicated the following. First, QI, with high importance and high performance for crisis management in fitness centers, included social distancing between employees and customers, equipping the fitness center with a thermometer, providing hand sanitizer, applying for government stimulus funds, notifying customers of new hours of operation, and ensuring employees practice good hand hygiene. This strong response was in part due to the threat of strong sanctions from the government if the measures were not implemented. Additionally, customers have been lost when they were not presented with the new operational guidance [32] at the beginning of the COVID-19 outbreak. In addition, the items mentioned in the study on the center selection attribute of fitness center participants before COVID-19 [33] are located in the QI, supporting the results of this study academically.

Most fitness centers in Korea are equipped with essential items for infection prevention, such as noncontact thermometers, hand sanitizers, and soap. In addition, thorough notifications and guidance on open hours of fitness centers are being provided in following the updates from government guidelines. Next, concerning emergency stimulus, 13 facilities that were closed due to COVID-19 were notified based on an announcement letter from the Korean government [34,35].

In other words, the items located in QI are rated as having high importance and high achievement due to the appropriate response of the fitness centers to changes in the Korean government's COVID-19 quarantine regulations.

Therefore, if the government's current quarantine guidelines and continuous interest and efforts in the items located in QI are maintained, this can improve the crisis management capabilities of the fitness center and overcome management difficulties. Second, the items in QII require intensive investment and improvement because they have high importance for crisis management but show relatively low achievement. As a result of this study, the main improvement items of fitness centers before COVID-19 were equipment, atmosphere, accessibility, and membership fees [36,37], but after the onset of the pandemic, these aspects were replaced by regular disinfection, seeking ways to cut rent, and applying for sports industry subsidies. Notably, while disinfection management was considered extensive, it was not implemented. Conversely, Planet Fitness, unlike its competitors, was actively coping with COVID-19. The details indicate that indoor fitness facilities started providing paper towels, hand sanitizers, and disinfecting sprays that are effective for preventing the spread of COVID-19 and also began to offer a variety of online fitness programs that allowed customers to continue to make use of their membership. By providing support for the operation of the fitness center and implementing a fitness program that can grant effective regular disinfection and infection prevention, it is possible to gain high customer trust and increase the efficiency of customer management.

In addition, regarding economic support for particularly hard-hit industries, plans for rent reduction and sports industry subsidies, as well as additional support policies, should be supported by the government, and benefits such as the application for sports industry subsidies, plans for rent reduction, and the deferment of principal and interest payments should be facilitated. 
Moreover, to make the fitness business sustainable, the government should formulate measures, such as employment maintenance subsidies, training support for business owners, extension of payment of employment charges, and health insurance premiums.

Third, it can be observed that the items in QIII have low importance and achievement for crisis management, and these should be gradually improved. In other words, cleaning of the interior props, installation of transparent partitions, application for disinfection of local quarantine, the planning and establishment of quarantine, guidance on refunds and automatic delays, instructions for quarantine regulations, and customer quarantine communication with the department are not being satisfactorily implemented.

However, factors located in QIII are not excluded from the quarantine system or are not being prioritized. Fitness center managers recognize that the cleanliness of props at the center and their quarantine plans, which are not listed in the government guidelines, are not working properly because they are perceived as low-intensity quarantine systems.

In particular, fitness center managers may not be aware of the importance of communicating with customers, as information on quarantine and general information are not quickly delivered to customers by the government. Mackert, Table, Yang, Bouchacourt, Woods, Bernhardt, and Wagner [38] indicate the importance of non-face-to-face communication with customers because a non-face-to-face culture is more commonly used in communication at present. The new normal is a method of communicating with customers through social networking services (SNS) and different kinds of online platforms, and the study suggests using such services and platforms to communicate with customers. Oh, Jang and Kim [39] indicate that the rate of acquiring fitness-related information through the internet and SNS is about $60 \%$ or more, and communication strategies with customers using online platforms such as SNS are essential at present. Therefore, for sustainable crisis management, various communication methods are needed.

Therefore, it is necessary for fitness center managers to manage factors such as the cleanliness of props located in QIII and to prepare a non-face-to-face content platform, such as Instagram, Facebook, YouTube, single-person online broadcasting, and live commerce. By providing information on quarantine and refunds and general information through such platforms, it is possible to determine the right direction for the customer management of fitness centers during the COVID-19 outbreak [40].

Fourth, QIV is an area of low importance but high achievement, and it is not necessary to put in the effort to improve the situation. Factors located in this area, such as controlling the meeting time between fitness center employees and customers, providing spare masks, ventilating toilet areas, and fielding inquiries about fitness center operating hours and membership systems over the telephone, are well maintained. These results indicate that government guidelines are being met by most fitness center managers. These factors cannot be considered as intensive improvement factors, but fitness center managers must maintain QIV to improve the completeness of the quarantine system for sustainable crisis management.

Moreover, if the government's social distancing policy is continued, the importance of factors located in the current quadrant may increase, and hence, it is necessary to prepare for a situation that requires further supplementation. Fitness center managers can receive high trust from customers and differentiate themselves from other centers if they create checklists based on factors located in the four abovementioned quadrants and continuously manage them.

\section{Conclusions}

The following conclusions were deduced contingent on the sustainable crisis management plan using IPA for fitness center managers during the COVID-19 pandemic. First, the provision of preventive measures and social distancing are being well implemented, and hence, it is necessary to maintain these at the present level. It should be noted that as the spread of COVID-19 continues for several months, preventive management including hand sanitizer and social distancing are essential elements in crisis management. Moreover, 
regarding disinfection management, a systematic plan should be established, along with preventive management and regular disinfection. Second, it is judged that special employment maintenance subsidies or emergency subsidies are necessary for fitness business owners in a difficult situation due to the closure of more than $70 \%$ of them and loss of sales. Therefore, the need for a plan prevails to maintain fitness centers by closely analyzing various economic types of support from the national and local governments. Third, as non-face-to-face interaction culture has become the new normal due to the pandemic, it is necessary to provide services with SNS and other distance-oriented means, alongside establishing new marketing plans. To diversify channels with customers and seek new online customer management in the era of COVID-19, it is necessary to consider building a non-face-to-face fitness content platform. Fourth, it is necessary to obtain the trust of the prospective customers by continuously managing and maintaining checklists for areas of relatively low importance and high achievement. In the operation of a fitness center, cleanliness is no longer an option, it is a necessity. Efforts to maintain proper humidity and supply fresh air are required for cleanliness, and this must be carefully checked through the list.

Finally, the following suggestions for future research are drawn. First, through the IPA analysis used in this study, it was possible to analyze the aspects that are considered crucial for dealing with crisis management, according to fitness center executives and managers suffering from management difficulties, and whether those aspects are being properly implemented. Various opinions can be collected on the establishment of management strategies in crises, and results can be derived for application in the given field. Second, this study was limited to fitness centers; thus, in the future, the results obtained from researching on diverse subjects such as indoor golf practice studios and Taekwondo gyms, which fall under the sports services sector, may be helpful for those working in these fields. Third, the global fitness industry is facing a crisis due to the spread of COVID-19; therefore, specific financial and administrative support from the government will be crucial. However, additional studies should be conducted to find ways that can be practically helpful for all working in the fitness industry. Fourth, it is judged that additional research is necessary not only for quantitative research but also for qualitative research to know the detailed atmosphere of the fitness field. In addition, because this study is field-oriented, the results will be provided to the Korea Fitness Industry Association.

Author Contributions: Conceptualization, J.-Y.K., T.-S.P.; formal analysis, J.-Y.K., T.-S.P.; validation, T.-S.P.; original draft preparation, T.-S.P.; writing-review and editing, J.-Y.K.; visualization, J.-Y.K., T.-S.P.; supervision, J.-Y.K. All authors have read and agreed to the published version of the manuscript.

Funding: This research received no external funding.

Institutional Review Board Statement: Not applicable.

Informed Consent Statement: Not applicable.

Data Availability Statement: Not applicable.

Conflicts of Interest: The authors declare no conflict of interest.

\section{References}

1. He, H.; Harris, L. The impact of COVID-19 pandemic on corporate social responsibility and marketing philosophy. J. Bus. Res. 2020, 116, 176-182. [CrossRef]

2. Korean Institute of Sport Science. Special Issue of a Desirable Direction of Sports Policy in the Era of Corona19. 2020. Available online: https:/ / www.sports.re.kr/pyxis-api/1/digital-files/a27be167-f6bc-4b91-9033-0bd701f3e702 (accessed on 19 May 2020).

3. Taku, K.; Arai, H. Impact of COVID-19 on athletes and coaches, and their values in Japan: Repercussions of postponing the Tokyo 2020 Olympic and Paralympic games. J. Loss Trauma 2020, 25, 623-630. [CrossRef]

4. Mastromartino, B.; Ross, W.J.; Wear, H.; Naraine, M.L. Thinking outside the 'box': A discussion of sports fans, teams, and the environment in the context of COVID-19. Sport Soc. 2020, 23, 1707-1723. [CrossRef]

5. Lee, S. A Study on the cultural and creative industry in the COVID-19 era. J. Converg. Cult. Technol. 2020, 6, 567-573. 
6. Suh, B.D.; Kwon, K.H. Impacts of the depression among the elderly in the South Korea community in COVID-19 pandemic. J. Health Inform. Stat. 2021, 46, 54-63. [CrossRef]

7. Chu, D.K.; Gu, H.; Chang, L.D.; Cheuk, S.S.; Gurung, S.; Krishnan, P.; Poon, L.L. SARS-CoV-2 superspread in fitness center, Hong Kong, China, March 2021. Emerg. Infect. Dis. 2021, 27, 2230-2232. [CrossRef]

8. Ong, A.K.S.; Prasetyo, Y.T.; Picazo, K.L.; Salvador, K.A.; Miraja, B.A.; Kurata, Y.B.; Young, M.N. Gym-goers preference analysis of fitness centers during the COVID-19 pandemic: A conjoint analysis approach for business sustainability. Sustainability 2021, 13, 10481. [CrossRef]

9. Norwegian Government. Enterprises with at Least 30 \% Fall in Revenue May Receive Compensation; Regjeringen: Oslo, Norway, 2020.

10. León-Quismondo, J.; García-Unanue, J.; Burillo, P. Best practices for fitness center business sustainability: A qualitative vision. Sustainability 2020, 12, 5067. [CrossRef]

11. Ker, A.P. Risk management in Canada's agricultural sector in light of COVID-19. Can. J. Agric. Econ. 2020, 68, 251-258. [CrossRef]

12. Fan, S.C. An Importance-Performance Analysis (IPA) of teachers' core competencies for implementing maker education in primary and secondary schools. Int. J. Technol. Des. Educ. 2020, 26, 1-27. [CrossRef]

13. Padlee, S.F.; Reimers, V.; Mokhlis, S.; Anuar, M.M.; Ahmad, A. Keep up the good work in research universities: An importanceperformance analysis. Australas. Mark. J. (AMJ) 2020, 28, 128-138. [CrossRef]

14. Esmailpour, J.; Aghabayk, K.; Vajari, M.A.; De Gruyter, C. Importance-Performance Analysis (IPA) of bus service attributes: A case study in a developing country. Transp. Res. Part A Policy Pract. 2020, 142, 129-150. [CrossRef]

15. Liskustyawati, H.; Riyadi, S.; Sabarini, S.S.; Waluyo, W.; Shidiq, A.A.P. Level of physical fitness of elderly people from 60 to 80 years old during a pandemic COVID-19. Health Sport Rehabil. 2020, 6, 27-38. [CrossRef]

16. Leandro, C.G.; Ferreira e Silva, W.T.; Lima-Silva, A.E. COVID-19 and Exercise-Induced Immunomodulation. Neuroimmunomodulation 2020, 27, 75-77. [CrossRef]

17. Noh, J.W.; Yoo, K.B.; Kwon, Y.D.; Hong, J.H.; Lee, Y.; Park, K. Effect of information disclosure policy on control of infectious disease: MERS-CoV outbreak in South Korea. Int. J. Environ. Res. Public Health 2020, 17, 305. [CrossRef] [PubMed]

18. Bundy, J.; Pfarrer, M.D.; Short, C.E.; Coombs, W.T. Crises and crisis management: Integration, interpretation, and research development. J. Manag. 2017, 43, 1661-1692. [CrossRef]

19. Branicki, L.J. COVID-19, ethics of care and feminist crisis management. Gend. Work Organ. 2020, 27, 872-883. [CrossRef]

20. Christensen, T.; Lægreid, P. Balancing governance capacity and legitimacy: How the Norwegian government handled the COVID-19 crisis as a high performer. Public Adm. Rev. 2020, 80, 774-779. [CrossRef]

21. Lee, S.; Yeo, J.; Na, C. Learning from the past: Distributed cognition and crisis management capabilities for tackling COVID-19. Am. Rev. Public Adm. 2020, 50, 729-735. [CrossRef]

22. Martilla, J.A.; James, J.C. Importance-performance analysis. J. Mark. 1977, 1, 77-79. [CrossRef]

23. Chiang, A.H.; Trimi, S. Impacts of service robots on service quality. Serv. Bus. 2020, 14, 439-459. [CrossRef]

24. Jou, R.C.; Day, Y.J. Application of revised importance-performance analysis to investigate critical service quality of hotel online booking. Sustainability 2021, 13, 2043. [CrossRef]

25. Albayrak, T.; Caber, M. Symmetric and asymmetric influences of service attributes: The case of fitness clubs. Manag. Leis. 2014, 19, 307-320. [CrossRef]

26. Athanasia, Z.; Vasiliki, K.; Maria, T. An Importance-Performance Analysis of personal training studios and gyms service quality. Int. J. Progress. Sci. Technol. 2020, 22, 403-411.

27. Mustafa, H.; Omar, B.; Mukhiar, S.N.S. Measuring destination competitiveness: An importance-performance analysis (IPA) of six top island destinations in South East Asia. Asia Pac. J. Tour. Res. 2020, 25, 223-243. [CrossRef]

28. Sepahvande, R. Importance Performance Analysis of Talent Absorbing Organization Factors. Organ. Resour. Manag. Res. 2020, 10, 75-94.

29. Sever, I. Importance-performance analysis: A valid management tool. Tour. Manag. 2015, 48, 43-53. [CrossRef]

30. Deng, J.; Pierskalla, C.D. Linking importance-performance analysis, satisfaction, and loyalty: A study of Savannah, GA. Sustainablilty 2018, 10, 704. [CrossRef]

31. Ma, L.; Christensen, T. Government trust, social trust, and citizens' risk concerns: Evidence from crisis management in China. Public Perform. Manag. Rev. 2019, 42, 383-404. [CrossRef]

32. Ratten, V. Coronavirus (COVID-19) and entrepreneurship: Changing life and work landscape. J. Small Bus. Entrep. 2020, 32, 503-516. [CrossRef]

33. Hau, H. The role of equity funds in the financial crisis propagation. Rev. Financ. 2020, 21, 77-108. [CrossRef]

34. Central Defense Countermeasure Headquarters Response Guidelines. Corona 19 Collective Facility Multisue Facility Response Guidelines, 2nd ed. 2020. Available online: http:/ / ncov.mohw.go.kr/guideBoardView.do?brdId=3\&brdGubun=35\&dataGubun= \&ncvContSeq=648\&contSeq=648\&board_id=\&gubun= (accessed on 21 July 2020).

35. Kim, H. IPA Research of Gym Selection Attribute for Cross Fit Participants. Master's Thesis, Kookmin University, Seoul, Korea, 2015.

36. Choi, W.; Kim, T. Study on realistic disaster management service implementation plan: Focusing on differential views in public and private experts. J. Korea Acad.-Ind. 2020, 21, 625-633.

37. Jang, W.Y.; Choi, K. Factors influencing choice when enrolling at a fitness center. Soc. Behav. Personal. 2018, 46, 1043-1056. [CrossRef] 
38. Mackert, M.; Table, B.; Yang, J.; Bouchacourt, L.; Woods, J.M.; Bernhardt, J.M.; Wagner, J.H. Applying best practices from health communication to support a university's response to COVID-19. Health Commun. 2020, 35, 1750-1753. [CrossRef] [PubMed]

39. Oh, I.; Jang, W.; Kim, S. Selling trust in cyber space: Social networking service (SNS) providers and social capital amongst netizens in South Korea. Asia Pac. Bus. Rev. 2018, 24, 196-211. [CrossRef]

40. Azer, J.; Alexander, M. Negative customer engagement behavior: The interplay of intensity and valence in online networks. J. Mark. Manag. 2020, 36, 361-383. [CrossRef] 